no changes in the viscera, and isinglass does not interfere with the normal regeneration of the blood plasma. H. E. Pugsley and R. F. Farquharson (Canad. Med. Assoc. $J ., 49,262$; 1943) gave the isinglass solution 58 times to 51 human patients to test it for pyrogenic and other toxic effects. A slight rise of temperature occurred on eight occasions, but no other unfavourable signs were noted in the other cases. When the isinglass was given to patients suffering from acute hæmorrhage, extensive burns, compound fractures and severe circulatory failure, the results were all good, and there were no toxic effects. The amount given varied from 200 c.c. to an infant to 8,800 c.c., given over a period of three days, to an adult.

\section{Oil from the Sunflower Plants}

There are probably few countries of the temperate regions which have a superabundance of fats and oils. War-time conditions, moreover, always accentuate any deficiency, and turn attention upon the possibilities of home production. A recent paper by $\mathbf{E}$. F. Hurt (J. Roy. Hort. Soc., 68, Part 11; Nov. 1943) gives the results of experience with the sunflower crop. Oil from the seeds of this crop is useful for edible and culinary purposes, for making margarine, as food for cattle and poultry, for canning fish and making fine soap. Its gastronomic value is equal to the finest olive oil. The crop is widely tolerant of soil types, but removes large quantities of soil nutrients, most of which are retained in the stalk, and can be returned to the ground after harvest. Sowing the seed at an even depth of $1 \frac{1}{2}-2$ in. appears to be important, and $7 \frac{1}{2} \mathrm{lb}$. of seed is needed to sow an acre by drill. Sunflower is a good cleaning crop, and appears to be but little affected by disease, though it is susceptible to wireworm attack and the depredations of birds at harvest time. Three semidwarf varieties--'Mars', 'Pole Star' and 'Southern Cross'-are suggested for Great Britain, and as the supply of fats and oils may be one of the most acute of post-war agricultural problems, the crop appears worthy of more extended trial.

\section{Thermoplastic Electric Cables}

A PAPER on thermoplastic cables, read by Dr. $\mathrm{H}$. Barron, J. N. Dean and T. R. Scett on February 10 before the Institution of Electrical Engineers, reviews the circumstances which have led to a considerable increase in the use of thermoplastic cables within the last few months. It is pointed out that the relative importance of such cables cannot yet be evaluated on a peace-time basis, for the economic level cannot be established and also synthetic rubber is now making its appearance. In order to establish a basis for evaluation, it is desirable to have a thorough understanding of the general characteristics of thermoplastic cables; this is attempted in the paper with particular reference to polyvinyl chloride cables. Indications are given of the polymer situation, the definition of a thermoplastic material and the resulting implications. The building-up and testing of polyvinyl compounds is discussed, and the manufacture, characteristics and uses of cables derived therefrom are considered in detail. A brief survey of other thermoplastics is followed by a comparison of poly. vinyl chloride with rubber.

It is concluded that suitably selected thermoplastic compounds can produce satisfactory wires and cables the characteristics of which are such that the corresponding rubber cables can be replaced by these thermoplastic cables. Oxidation need no longer be considered as the predominant factor in determining life; there are still restricting factors which prevent thermoplastic cables from being worked at temperatures appreciably in excess of those suitable for rubber cables; but these factors are of a different nature and may be countered by development and design along lines which would be impracticable for rubber. The cable engineer has aequired a range of alternate materials which, while they present problems of their own, promise interesting solutions for some existing problems. A period of rapid development of wires and cables of compound characteristics must inevitably ensue so soon as free choice, on an economic besis, of such materials is practicable.

\section{Industrial Fire Risks}

IN a paper read in London on December 9 before the Institution of Electrical Engineers, Messrs. W. Fordham Cooper and F. H. Mann describe first the classification of buildings and structural materials in relation to fire resistance, and then deal with the hazard from various industrial materials and processes and the special precautions which should be adopted in providing and operating electrical installations in view of these risks. Flame-proof and intrinsically safe constructions are briefly described. The second part of the paper illustrates the application of the matter discussed in the first part; but, as it is impossible to deal with every risk, attention has been particularly paid to the heavy chemical (gas, coke and by-product) and textile industries by way of examples, although some other matters, notably switch and transformer oil-fire risks, are also mentioned.

\section{Tuberculosis in Paraguay}

Is a recent article (Bol. Of. San. Panamer., 22, 318; 1943), Drs. A. R. Ginés, A. Alvarez and M. Mercado state that in June 1941 the control of tuberculosis in Asuncion was started under the direction of $\mathrm{Dr}$. Angel R. Ginés, and 40,000 persons were examined in the course of a year. In November 1941, the Ministry of Health amended a decree of 1938 making compulsory the X-ray examination of all public officers, public and private employees, teachers, students, labourers, etc. The examination consisted of a tuberculin test, pulmonary röntgenograms or sometimes merely fluoroscopy and a rapid examination of the skin and mucous membranes. The Tuberculosis Dispensary at Asuneión, which was founded in 1922, during the first ten years of its existence could treat only general advanced tuberculosis owing to the lack of modern means of diagnosis; but in 1932 a chair of tuberculosis was created and the campaign against tubercułosis now includes a röntgenologieal and tuberculin survey and a morbidity and mortality survey in the urban areas of the Republic, diagnosis of the disease by modern methods, effective isolation or quarantine of contagious cases, creation of schools for the tuberculous or pre-tuberculous, vaceination of the newborn with B.C.G., economic and social improvements, creation of an Institute of Social Security, intensive educational propaganda, and eradieation of tuberculous animals. The tukerculosis death-rate is caleulated to be 199.9 per 100,000 , and its relation to general mortelity is $15 \cdot 50$ per cent. Tubereulosis with other diseases of the lungs caused a third of the deaths in 1941. Relation to the standard of living is supported by the following death-rates : 
merchants 3 per eent, intellectuals 6 per cent, seam. stresses, domestic helpers and other employees 10-11 per cent, farmers 22 per cent and labourers 29 per cent. The highest death-rates were noted in the 1-5 year old group and in the $20-40$ group.

\section{Immunizations in Large Cities of the United States}

IN a recent paper (Public Health Rep., 58, 1121 ; 1943), Selwyn D. Collins, head statistician, and Clara Councill, assistant statistician of the United States Public Health Service, record their study of immunization against diphtheria, smallpox, scarlet fever and typhoid fever based on a canvas of 213,931 households in 23 cities of 100,000 or more inhabitants. Their conclusions are as follows. Immunizations against scarlet fever and typhoid fever are negligible compared with those against diphtheria and smallpox. In the pre-school age immunizations against diphtheria are more frequent than vaceinations against small-pox, but after five years the reverse is true. There was considerable geographical variation in the extent of immunization against the diseases. In the north, for example, the percentages of native, foreign and coloured children of specific ages immunized against diphtheria are approximately the same, while in the south a higher percentage of the native whites is immunized than of the foreign whites or coloured.

\section{Cattle Fodder from Wood}

According to an annotation entitled "Fir to Fodder" in the January issue of the Anglo-Swedish Review, the Swedish forests provide a practically inexhaustible store of timber which can be converted into fodder for horses and eattle. It can be made from the wood of the fir tree, but pine can also be used. The raw wood has no food value for man, even if ground to a fine flour, as there are no enzymes or micro-organisms in the human digestive tract to dissolve the wood and its cellulose. Cattle and horses, however, can absorb it almost entirely because their digestive organs contain bacteria which can break down the pure cellulose into products which can be absorbed into the blood. To make the fodder cellulose more nutritive and palatable to animals, molasses and sometimes phosphates or salts are added at the pulp mill. Alcohol is also obtained during the process of making fodder pulp.

\section{Research in Human Nutrition}

The Medical Research Council has established a Unit for Research in Human Nutrition as part of its staff organization, and Dr. B. S. Platt has been appointed its director. Temporary accommodation has been provided at the National Hospital for Nervous Diseases, Queen Square, London. Some part of the investigations undertaken by the Unit will be directed towards nutrition problems in the tropics. Among other things, Dr. Platt will continue the work, for which he joined the Couneil's staff in 1938, of co-ordinating a programme of nutritional investigations in the Colonies by arrangement between the Colonial Office and the Council.

\section{Properties and Uses of Diamonds}

A RESEARCH department has been established by the Diamond Trading Company, Ltd., the London office of which is at 32-34 Holborn Viaduct, London,
E.C., under the management of Mr. Paul Grodzinski, assisted by a staff of five. The Department is engaged in investigations into the properties of diamonds, their preparation for use and, in particular, their application in industry. An extensive library, built up over a long period of years by Mr. Grodzinski, forms part of the Department, and its information service is available free of charge.

\section{The Night Sky in March}

Fuls moon occurs on March 10d. 00h. 28m. U.T., and new moon on March 24d. 11h. 36m. The following conjunctions with the moon take place: March 2d. 08 h., Mars $6^{\circ}$ N. ; March 2d. 13h., Saturn $3^{\circ}$ N. ; March 7d. 11h., Jupiter $0 \cdot 1^{\circ}$ S. ; March 22d. 16h., Venus $2^{\circ}$ N.; March 29d. 23h., Saturn $2^{\circ}$ N.; March 30d. 18h., Mars $5^{\circ} \mathrm{N}$. The following occultations of stars brighter than magnitude 6 take place : March 3d. 19h. 59.4m., v Gemi. (D); March 28d. 20h. 31.1m., 63 Tauri $(D)$; March 31d. 19h. 23.5m., $\zeta$ Gemi $(D)$. The times refer to Greenwich and $D$ refers to disappearance. Mercury rises at $6 \mathrm{~h} .44 \mathrm{~m}$. and $6 \mathrm{~h} .05 \mathrm{~m}$. at the beginning and end of the month, but is too close to the sun for good observation. The planet is in superior conjunction on March 17. Venus, a morning star, rises at $5 \mathrm{~h} .34 \mathrm{~m}$. and $5 \mathrm{~h} .14 \mathrm{~m}$. at the beginning and end of the month, and can be seen only with difficulty. Mars sets at $2 \mathrm{~h}$. $54 \mathrm{~m}$. and $2 \mathrm{~h}$. at the beginning and end of the month and can be seen in the early part of the night. On March 7d. 15h. there is a conjunction between Mars and Saturn, Mars being $3 \cdot 4^{\circ} \mathrm{N}$. Jupiter is visible throughout the night, setting at $6 \mathrm{~h} .15 \mathrm{~m}$. and $4 \mathrm{~h} .13 \mathrm{~m}$. at the beginning and end of the month. Saturn is visible in the early part of the night, setting at $2 \mathrm{~h} .40 \mathrm{~m}$. and $0 \mathrm{~h} .49 \mathrm{~m}$. at the beginning and end of the month. Spring equinox begins on March 20d. 18h.

\section{Announcements}

Dr. Harry R. Ricardo, the well-known consulting engineer and authority on the internal combustion engine, has been elected president of the Institution of Mechanica] Engineers for the year 1944-45.

J. P. Rutland (New Phyt., 40, $210 ; 1941$ ) has published a supplement to the Merton Catalogue of Chromosomes of British Plants. The new list contains about a hundred new chromosome numbers discovered by the author and other workers, and is a valuable contribution to the analysis. of the British flora.

THE following appointments have recently been made in the Colonial Service: H. Doggett to be agricultural officer, Tanganyika; A. J. Browning to be assistant conservator of forests, Sierra Leone; S. L. Finding to be assistant conservator of forests, British Honduras; H. Tordoff to be assistant conservator of forests, Trinidad; A. W. Vaughan to be veterinary officer, Jamaica; Dr. E. F. Thompson to be fishery officer, Jamaica ; D. W. Duthie (chemist, British Guiana) to be soil chemist, East African Agricultural Research Bureau, Tanganyika; A. F. A. Lamb (assistant conservator of forests, Nigeria) to be senior assistant conservator of forests, British Honduras.

ERratum. In the paragraph entitled "Road Research" in NATURE of February 12, p. 193, the names of Major $\mathbf{H}$. E. Aldington (chairman) and $\mathbf{M r}$. W. Savage were inadvertently omitted from the list of members of the committee. 